\title{
下水污泥焼却灰のアルカリ溶出による リン回収量の増大に関する研究
}

\author{
吉田佳子 1 ・野池達也 2 \\ 1川崎市役所 下水道管理部（テ210-8577 神奈川県川崎市川崎区宮本町 1 番地） \\ E-mail:yoshida-yo@city.kawasaki.jp \\ 2 フェロー会員 工博 東北大学教授 大学院工学研究科 土木工学専攻（テ9980-8579 宮城県仙台市青葉 \\ 区荒巻字青葉06）.
}

\begin{abstract}
リン鉱石は，世界的に枯渴の懸念されている資源の一つであり，下゙水污泥はリン鉱石の代替資源として 有望視されている. 本研究では, アルカリ溶出による下水污泥焼却灰からのリン回収において, 圧送污泥 に凝集剤としてPAC，アルミン酸ナトリウムおよびポリ硫酸第二鉄を添加することにより，添加時pH がリ ン放出抑制に及ぼす影響, 各凝集剤のリン放出抑制効果および得られた焼却灰のアルカリ溶出特性につい て, リン回収割合の増大を目的として検討した。PACは使用最適 $\mathrm{pH}$ 範囲が広く, pH4においてアルカリ溶 出可能なリンの割合が $49 \%$ か $84 \%$ に増大した.
\end{abstract}

Key Words : sewage sludge, incinerator ash, phosphorus recovery, alkaline elution, pH, coagulant

\section{1.はじめに}

下水道普及率の増大に伴い，下水污泥発生量は，年々 増大の一途を辿っている。その発生量は全国で198万 Ds $-t$ ·年 ${ }^{-1}$ (平成12年度) であり，埋立地の不足，悪臭な どの対策のため, このうち79\%が焼却処理され，36万t・ 年 ${ }^{-1}$ の下水焼却死（以下，「焼却死」とする。）が発生 している1．しかし，この下水污泥を燒却処分する際， 多量のリンを含む返流水が発生し, 受入先の下水処理過 程に過大な負荷を与え, 放流水中のリン濃度の上昇をも たらしている2，3).一方，閉鎖性水域の富栄養化防止の観 点から, 第5次総量規制が, 既設の施設については平成16 年4月から開始される.このような流れを受け, 全国で下 水からのリン・窒素除去を目的とし, 高度処理施設が次々 と稼働を始めている゙1)。の高度処理により発生する污 泥は, 污泥処理過程で, これまでより高濃度のリンを放 出することが報告らされており, 返流水受入処理場の負 荷をさらに增大させる。

一方，リン鉣石は世界的に枯渇の懸念されている資源 の一つである。しかし，我が国ではリン鉱石は産出され
ず, 全量 (約 100 万 $\mathrm{t} \cdot$ 年 $^{-1}, \mathrm{P}_{2} \mathrm{O}_{5}$ 換算で約 35 万 $\mathrm{t} \cdot$ 年 ${ }^{-1}$ )を, 海外からの輸入に頼っている ${ }^{6)}$. 焼却灰には下水から移 行したリンが15〜30\%含まれており, 全国から発生する焼 却灰に含まれるリン量は5〜 10 万t $\mathrm{P}_{2} \mathrm{O}_{5}$ ・年 ${ }^{-1}$ と推測される. これはリン鉣石として輸入されているリンの14〜28\%に 相当する7).これらのことから焼却灰をリン鉱石の代替 品として使用できれば，枯渇の可能性のないリン資源を 確保できる.このため, 著者らは焼却灰からリンなどの 資源を回収する研究を行ってきた. その中で, 焼却灰を アルカリ溶出することで焼却灰から有害な重金属を溶出 させずに，リンとアルミニウムのみを溶出させることに 成功した8)、9)、(10)、11)。また，リン酸アルミニウムが焼却灰 中のリン回収に重要な役割を担うことを明確にし ${ }^{12)}$, 図 -1に示す資源循環システムを提案した。しかし，アルカ リ溶出では焼却灰に含まれるリンのうち, 約 $50 \%$ しか溶 出させることができなかった。

そこで, 返流水中のリン, 特に溶解性リンによる負荷 を低減し, 焼却灭からアルカリ溶出可能なリンの割合を 増大させるため, 凝集剤による污泥からのリンの放出抑 制実験を行い，これら凝集剤が焼却灰のアルカリ溶出に 


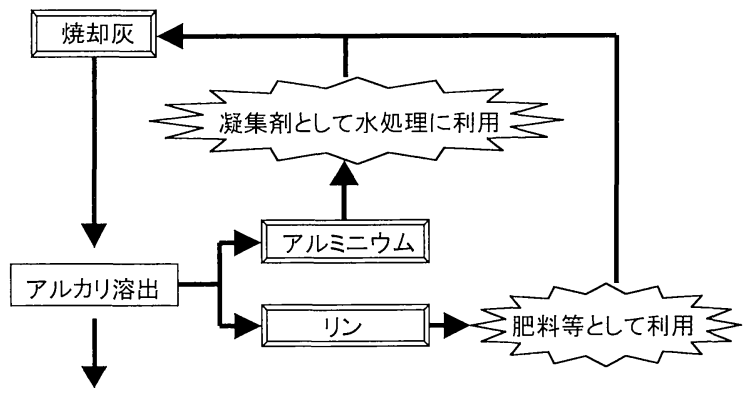

残さはセメント原料へ

図-1 アルカリ溶出による資源循環システム

\section{及ぼす影響を明らかにした。}

凝集剤を使用する場所は水処理過程，圧送污泥，污泥 焼却施設の返流水設備等が考えられる. 返流水設備に凝 集剤を使用する方法は，川崎市でも行われており，様々 なところで実用化されている. しかし, 返流水設備では, すでに多くのリンが污泥から放出されており，同時に放 出された有機酸等を多く含むため, 多くの凝集剂を添加 しなければならない(13), 14). また，水処理過程に凝集剤を 使用し, 処理水中のリン濃度を低減させる方法は, 様々 な機関で実用化されている(5), 16), 177, 18, 19). これらで使用さ れた凝集剤が返流水に与える影響は，水処理過程での 様々な要因が複雑に作用し合うため, 解明されていない.

本研究は凝集剂のリン放出抑制効果を解明するために, 様々な要因が複雑に作用し合う水処理過程中ではなく,

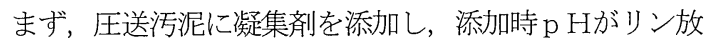
出抑制に及ぼす影響と，凝集剂ごとのリン放出抑制効果
の特性および得られた焼却灰中のリンのアルカリ溶出特 性について検討し，焼却灰中のアルカリ溶出可能なリン の割合の増大を目指したものである。

\section{2. 実験方法}

（1）実験に使用する圧送污泥と分析方法について

川崎市等々力水処理センターでは, 標準活性污泥法で 発生した余剩污泥と, 最初沈殿池で発生した初沈污泥と を混合し，圧送污泥として入江崎総合スラッジセンター へ送泥している，実験は採取した圧送污泥に直ちに各種 凝集剤を加え，空気が入らないよう擋找した後，所定時 閒静置した，その後，遠心分離でS S 分を分離し，その 上澄みをさらに $5 \mathrm{C}$ のろ紙でろ過後, 溶解性リン酸イオ ン態リン（以下， s-OPとする）および溶解性全リン（以 下， s-TPとする）について分析を行った．分析の手順と 測定されるリンの形態を図-2に示す． S-TPとは５Cのろ 紙を通過する低分子リン酸化合物およひ $\mathrm{PO}_{4}{ }^{3-}$ イオン等の 溶解性リンの総量である. また, $\mathrm{s}-\mathrm{OP}$ とはこのうち $\mathrm{PO}_{1}^{3-}$ イオンで存在するリンであり，嫌気状態で污泥から昍き 出されるリンは，ほとんどがこの形態であると考えられ る ${ }^{20)}$. その他，分析を行った各項目についての分析方法 を表-1に，使用した凝集剤の性状を表-2に示寸．また使 用した凝集剂のうち，アルミン酸ナトリウムは焼却灰を アルカリ溶出し, 得られたアルカリ溶液からナトリウム 法"1によって，実際に焼却灰から回収されたものを使用

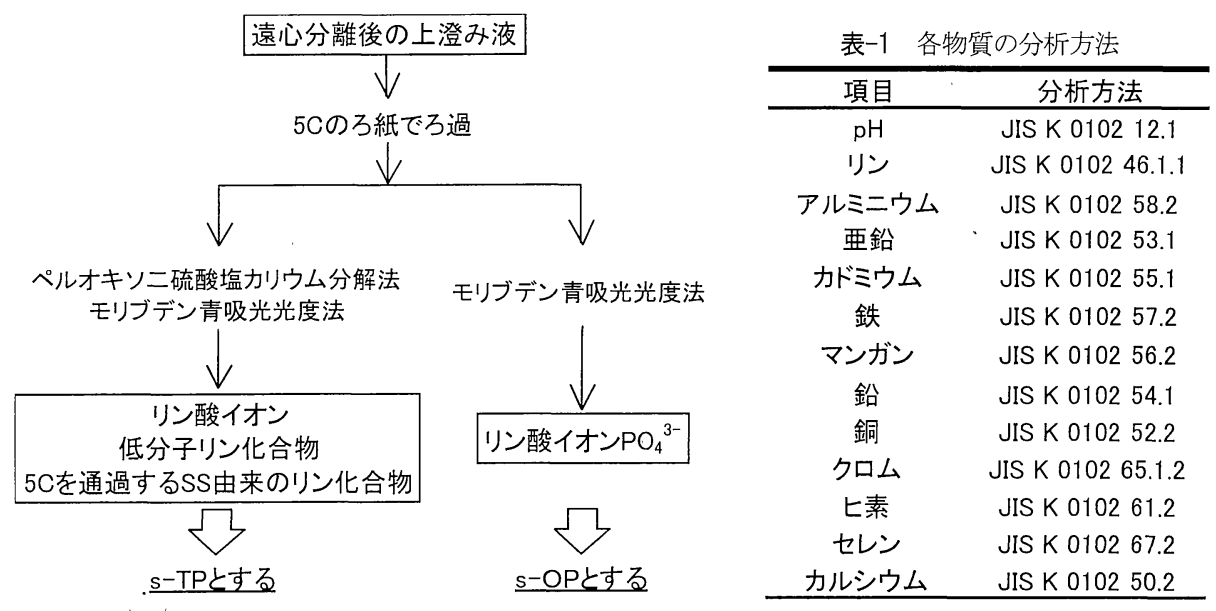

図-2 リンの形態と分析方法

表-2 実験で使用した凝集剤の性状

\begin{tabular}{ccccc}
\hline 名称 & 分類 & $\mathrm{pH}$ & \multicolumn{2}{c}{ 有効成分濃度 } \\
\hline $\mathrm{PAC}($ ポリ塩化アルミニウム) & アルミニウム系凝集剤 & 酸性 & $62000 \mathrm{mgAl} / \mathrm{l}$ & $(2300 \mathrm{mmol} / \mathrm{l})$ \\
アルミン酸ナトリウム & アルミニウム系凝集剤 & アルカリ性 & $30000 \mathrm{mgAl} / \mathrm{I}$ & $(1100 \mathrm{mmol} / \mathrm{I})$ \\
ポリ硫酸第二鉄 & 鉄系凝集剂 & 酸性 & $150000 \mathrm{mgFe} / \mathrm{l}$ & $(2700 \mathrm{mmol} / \mathrm{I})$ \\
\hline
\end{tabular}


した.

\section{（2）各凝集剂の使用最適 $\mathrm{p} H$ 確認}

アルミニウムイオンが最も沈殿しやすいのは $\mathrm{p} \mathrm{H8}$ 付 近であるが，ケイ酸，重合ケイ酸およびフミン酸などの イオンの共存量が多くなれば啇正 p Hは酸性側に移り p H8 では沈殿しなくなる ${ }^{11)}$. 図-1 に示寸資源循環を効率 よく行うため, できる限り, リンを污泥内部に留めるこ とが重要と考えられる，そこで各凝集剤が最も効率よく リンの放出抑制能力を発揮する使用最適 $\mathrm{p} \mathrm{H}$ 確認を行 った.

また，凝集剂中のアルミニウムイオンおよび鉄イオン は式(1)および式(2)に従い，水中のオルトリン酸イオン と反応し，リン酸アルミニウムおよびリン酸鉄を生成す る．これを沈殿除去することで排水中のリンを除去する ことができる. しかし，排水中に存在する炭酸水素イオ ン (アルカリ度) および有機酸等により式(3)から (6)の ように，アルミニウムイオンおよび鉄イオンが消費され るため ${ }^{13)}$, 11)，凝集剤はリン除去のみに必要とされる凝集 剂量の 3 倍 mol 以上の凝集郕添加が必要と言われている 21), 22).

$$
\begin{gathered}
\mathrm{Al}^{3+}+\mathrm{PO}_{4}{ }^{3-} \rightarrow \mathrm{AlPO}_{4} \downarrow \\
\mathrm{Fe}^{3+}+\mathrm{PO}_{4}{ }^{3-} \rightarrow \mathrm{FePO}_{4} \downarrow \\
\mathrm{Al}^{3+}+3 \mathrm{HCO}_{3}{ }^{-} \rightarrow \mathrm{Al}(\mathrm{OH})_{3} \downarrow+3 \mathrm{CO}_{2} \\
\mathrm{Fe}^{3+}+3 \mathrm{HCO}_{3}{ }^{-} \rightarrow \mathrm{Fe}(\mathrm{OH})_{3} \downarrow+3 \mathrm{CO}_{2} \\
\mathrm{Al}^{3+}+3\left(\mathrm{C}_{2} \mathrm{O}_{4}\right)^{2-} \rightarrow \mathrm{Al}\left(\mathrm{C}_{2} \mathrm{O}_{4}\right)_{3}{ }^{3-} \\
\mathrm{Fe}^{3+}+3\left(\mathrm{C}_{2} \mathrm{O}_{4}\right)^{2-} \rightarrow \mathrm{Fe}\left(\mathrm{C}_{2} \mathrm{O}_{4}\right)_{3}{ }^{3-}
\end{gathered}
$$

実験で使用した圧送污泥には，全リンとして年平均 $220 \mathrm{mg} / 1$ および s-OP として $30 \mathrm{mg} / 1$ のリンが含まれてい る. そこで，実験は送泥前の圧送污泥に，当初含まれる と予想される $30 \mathrm{mg} / 1$ の $\mathrm{s}-\mathrm{OP}$ に対して 3 倍 mol 量のアル ミニウムもしくは鉄イオンを含む凝集剤を添加した。凝
集剤添加後， 3 分後の p Hが所定 p Hになるように硫酸 および水酸化ナトリウムで $\mathrm{p} \mathrm{H}$ 調整を行った．静置後， 30 分，1，2，4および 20 時間で，試料の一部を採取し遠 心分離を行った. 遠心分離後, 上澄み液を $5 \mathrm{C}$ のろ紙で 濾過後, s-OPおよびs-TPの分析を行った.

また，凝集剂を添加しない圧送污泥のリン放出につい ても同様に分析を行った。

\section{（3）凝集剂添加した圧送污泥から得られた焼却灰の溶出} 特性

著者らはこれまで焼却灰のアルカリ溶出について実験

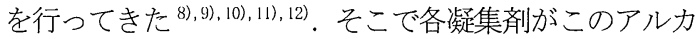
リ溶出の割合にどのような影響を及ぼすかについて検討 するために，凝集剤を添加して得られた焼却灰の溶出特 性の比較実験を行った．実験は圧送污泥に対して，各凝 集剂を 3 倍 mol 量添加し, 硫酸を用いて p H4 に調整し, 20 時間静置後，遠心分離を行い上澄みと SS 分とに分離 した. 分離された上澄み液は(2)の実験と同様，5 Cのろ 紙でろ過後，鉄，アルミニウムおよびリンについて分析 を行った。 また，分離した SS 分は電気炬で $800^{\circ} \mathrm{C} ， 3$ 時 間焼却し焼却灰として回収した，次に，得られた焼却灰 $0.5 \mathrm{~g}$ を $10 \%$ 濃度の水酸化ナトリウム溶液 $50 \mathrm{ml}$ で溶出し, アルカリ溶出可能な全てのリンとアルミニウムを溶出さ せ，その溶出濃度について分析を行った。 また，凝集剤 添加後, $\mathrm{pH}$ 調整を行わなかった試料についても同様に 上澄みの分析，得られた焼却灰のリンおよびアルミニウ ム含有試験およびアルカリ溶出試験を行った。

\begin{tabular}{|c|c|c|c|c|c|c|c|c|c|c|c|c|}
\hline \multirow[b]{2}{*}{ 時間 } & \multicolumn{3}{|c|}{ 無添加 } & \multicolumn{3}{|c|}{$\mathrm{pH} 3$} & \multicolumn{3}{|c|}{$\mathrm{pH} 4$} & \multicolumn{3}{|c|}{$\mathrm{pH} 5.1$} \\
\hline & $\mathrm{pH}$ & $\mathrm{s}-\mathrm{O}$ & $\overline{s-T P}$ & $\mathrm{pH}$ & $\mathrm{s}-\mathrm{OP}$ & $s-T P$ & $\mathrm{pH}$ & $\mathrm{s}-\mathrm{OP}$ & $\overline{s-T P}$ & $\mathrm{pH}$ & $\mathrm{s}-\mathrm{OP}$ & $s-T P$ \\
\hline 0.5 & 6.3 & 38 & 40 & 3.4 & 5.9 & 6.6 & 4.2 & 0.29 & 0.63 & 5.4 & 0.36 & 0.91 \\
\hline 1 & 6.3 & 37 & 39 & 3.4 & 5.8 & 6.6 & 4.3 & 0.25 & 0.61 & 5.4 & 0.41 & 0.97 \\
\hline 2 & 6.2 & 41 & 42 & 3.4 & 5.1 & 6.0 & 4.3 & $<0.25$ & 0.48 & 5.5 & 0.48 & 1.1 \\
\hline 4 & 6.3 & 43 & 45 & 3.5 & 5.2 & 6.4 & 4.4 & $<0.25$ & 0.40 & 5.6 & 0.41 & 0.92 \\
\hline 20 & 6.1 & 48 & 49 & 3.5 & 4.2 & 5.9 & 4.6 & $<0.25$ & 0.32 & 5.9 & 0.97 & 1.4 \\
\hline
\end{tabular}

\section{3. 実験結果と考察}

\begin{tabular}{|c|c|c|c|c|c|c|c|c|c|}
\hline \multirow[b]{2}{*}{ 時間 } & \multicolumn{3}{|c|}{ pH5.5 } & \multicolumn{3}{|c|}{$\mathrm{pH} 5.9$} & \multicolumn{3}{|c|}{$\mathrm{pH} 6.3$} \\
\hline & $\mathrm{pH}$ & $\mathrm{s}-\mathrm{OF}$ & s-TP & $\mathrm{pH}$ & $\mathrm{s}-\mathrm{OP}$ & $s-T P$ & $\mathrm{pH}$ & s-OP & S-TP \\
\hline 0.5 & 5.7 & 0.26 & 0.64 & 6.0 & 0.20 & 0.72 & 6.4 & 0.19 & 1.0 \\
\hline 1 & 5.7 & 0.28 & 0.76 & 6.0 & 0.22 & 1.0 & 6.4 & 0.26 & 1.1 \\
\hline 2 & 5.8 & 0.68 & 1.1 & 6.1 & 0.64 & 1.5 & 6.4 & 0.84 & 1.9 \\
\hline 4 & 5.8 & 0.94 & 1.4 & 6.1 & 1.1 & 2.0 & 6.4 & 1.7 & 3.0 \\
\hline 20 & 6.0 & 1.5 & 1.9 & 6.1 & 2.3 & 2.9 & 6.3 & 3.3 & 4.2 \\
\hline
\end{tabular}

（1）凝集剂の使用最適 $\mathrm{p} H$ Hリン放出抑制効果

焼却灰からリンをより多く回収するためには，より多 くのリンを污泥中に留めることが重要と考えられる。そ

表-3 PAC 添加後の上澄み中のリン分析結果

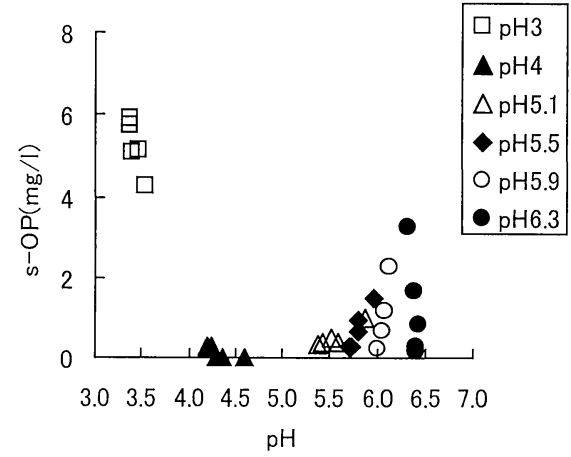

図-3 PACのpHと残留リン濃度

s-TP およびs-OP の単位はmg/l 
こで各凝集剤が最も効率よくリンの放出抑制能力を発揮 する使用最適 $\mathrm{p} \mathrm{H}$ 確認を行った。

\section{a) PACの使用最適 $\mathrm{p}$ Hとリン放出抑制効果}

PACを加え各 p Hに調整した後の圧送污泥と, 凝集剂を 添加しない圧送污泥の上澄み中の $\mathrm{s}-\mathrm{OP}$ およびs-TPの分析 結果を表一䛃す，凝集剤を添加しない圧送污泥は時間 経過とともに上澄み中にリンを放出し，20時間後， s-TP の值は $49 \mathrm{mg} / 1$ となった。この時, $\mathrm{s}-\mathrm{TP}$ と $\mathrm{s}-\mathrm{OP}$ 差はほと んど変化しておらず，圧送污泥から放出されるリンのほ とんどはS-OPで示されるリン酸イオン態リンであること が確認された。

圧送污泥は3分間かけて設定値 $\mathrm{p} \mathrm{H}$ Hなるように調整 を行ったが，その緩衝作用のため時間経過とともに $\mathrm{pH}$ が変動した。実験の結果からアルミニウム系凝集㓮では この変動後の p Hと残留リン濃度 $(\mathrm{s}-\mathrm{OP})$ との間に相関 が見られたため，設定 $\mathrm{p} \mathrm{H}$ H゙とに変動後の $\mathrm{p} \mathrm{H}$ と $\mathrm{s}-\mathrm{OP} の$ 結果を図-3に示した，結果からPACでは $\mathrm{p} \mathrm{H}$ H以下， $\mathrm{pH}$ 5.5以上でわずかではあるが, 時間経過とともに污泥の緩 衝作用により，設定 $\mathrm{p} \mathrm{H}$ Hら変動しリンが放出される傾 向が見られた。図一結果から使用最適 $\mathrm{p} \mathrm{H}$ 求めると, p H4〜5. 5付近であり，pH4に調整した場合，最もその 効果が大きかった．結果から使用最適 $\mathrm{p} \mathrm{H}$ H処理水等に 使用する場合に比べ23), 低 $\mathrm{p} \mathrm{H}$ 側に移動し, さらに領域
も狭い結果となった.これは圧送污泥に含まれる塩類が, アルミニウム化合物の沈殿生成に何らかの影響を与えて いると考えられる21),25). しかし，PACのリン除去性能は p H4以上では20時間放置後も, 上澄み液中のリン濃度は $4 \mathrm{mg} / 1$ 以下と非常に良好な結果が得られた。

圧送污泥の初期 $\mathrm{pH}$ H $\mathrm{p} \mathrm{H6}$ 付近であり，PAC は強酸 性の凝集剤であることから, PAC 添加直後の圧送污泥の p Hはp H5. 5 付近となる.このことから, PACでは p H 調整を行わず，PAC の酸性のみでリンの放出を抑制でき る結果となった。

b) アルミン酸ナトリウムの使用最適 $\mathrm{p}$ Hとリン放出抑制 効果

凝集剤としてアルミン酸ナトリウムを加えたときの上 澄み中の $\mathrm{s}-\mathrm{OP}$ および $\mathrm{s}-\mathrm{TP}$ の分析結果を表-4 に示す. PAC と同様に図-4 よりアルミン酸ナトリウムの使用最適 p Hは，p H4〜5 付近であった. しかし, PAC と異なり, この $\mathrm{pH}$ H領域からはずれるとリン除去性能は急激に低下 する結果となった．このときの $\mathrm{s}-\mathrm{TP}$ と s-OP の差を図-5 に示した. 図-5 が示寸結果からアルミン酸ナトリウムは 使用最適 $\mathrm{p}$ H以外では， s-TP と s-OP の差が大きく，上. 澄み中に s-OP だけでなく低分子リン化合物および $5 \mathrm{C}$ のろ紙を通過する SS 分由来のリンが増加したことが確 認された。これらが上澄み中に増加することで, 圧送污

表-4 アルミン酸ナトリウム添加後の上澄み中のリン分析結果

\begin{tabular}{|c|c|c|c|c|c|c|c|c|c|c|c|c|}
\hline \multirow[b]{2}{*}{ 時間 } & \multicolumn{3}{|c|}{$\mathrm{pH} 3$} & \multicolumn{3}{|c|}{$\mathrm{pH} 4$} & \multicolumn{3}{|c|}{$\mathrm{pH} 4.5$} & \multicolumn{3}{|c|}{$\mathrm{pH} 5$} \\
\hline & $\mathrm{pH}$ & $\mathrm{s}-\mathrm{OP}$ & $\overline{s-T P}$ & $\mathrm{pH}$ & s-OP & $s-T P$ & $\mathrm{pH}$ & s-OP & $\overline{s-T P}$ & $\mathrm{pH}$ & s-OP & $\overline{s-T P}$ \\
\hline 0.5 & 3.2 & 22 & 27 & 4.5 & 0.82 & 2.6 & 4.9 & 2.0 & 4.5 & 5.2 & 1.7 & 3.6 \\
\hline 1 & 3.2 & 22 & 27 & 4.5 & 0.74 & 2.5 & 5.0 & 2.1 & 4.4 & 5.2 & 1.7 & 3.6 \\
\hline 2 & 3.3 & 21 & 26 & 4.7 & 0.75 & 2.6 & 5.2 & 1.6 & 3.9 & 5.3 & 1.9 & 4.1 \\
\hline 4 & 3.3 & 21 & 27 & 4.7 & 0.80 & 2.6 & 5.2 & 2.2 & 4.4 & 5.4 & 1.9 & 3.9 \\
\hline 20 & 3.3 & 19 & 27 & 4.8 & 0.80 & 2.7 & 5.6 & 2.4 & 4.6 & 5.6 & 2.1 & 4.3 \\
\hline
\end{tabular}

\begin{tabular}{|c|c|c|c|c|c|c|c|c|c|c|c|c|}
\hline \multirow[b]{2}{*}{ 時間 } & \multicolumn{3}{|c|}{$\mathrm{pH} 5.5$} & \multicolumn{3}{|c|}{$\mathrm{pH} 6$} & \multicolumn{3}{|c|}{$\mathrm{pH} 7$} & \multicolumn{3}{|c|}{$\mathrm{pH} 8$} \\
\hline & $\mathrm{pH}$ & $\mathrm{s}-\mathrm{OP}$ & s-TP & $\mathrm{pH}$ & $\mathrm{s}-\mathrm{OP}$ & $-\mathrm{TP}$ & $\mathrm{pH}$ & $\mathrm{s}-\mathrm{OP}$ & i-TP & $\mathrm{pH}$ & $\mathrm{s}-\mathrm{OP}$ & $5-T P$ \\
\hline 0.5 & 5.9 & 1.7 & 3.3 & 5.8 & 8.0 & 12 & 7.0 & 21 & 28 & 7.5 & 27 & 33 \\
\hline 1 & 6.0 & 1.8 & 4.0 & 5.9 & 11 & 15 & 7.0 & 17 & 24 & 7.5 & 21 & 28 \\
\hline 2 & 5.9 & 1.9 & 4.1 & 5.9 & 8.3 & 11 & 7.0 & 21 & 27 & 7.4 & 23 & 30 \\
\hline 4 & 5.9 & 2.0 & 3.7 & 6.0 & 11 & 15 & 7.0 & 19 & 25 & 7.3 & 24 & 29 \\
\hline 20 & 6.9 & 4.6 & 7.2 & 6.1 & 13 & 16 & 6.6 & 12 & 16 & 6.8 & 15 & 18 \\
\hline
\end{tabular}

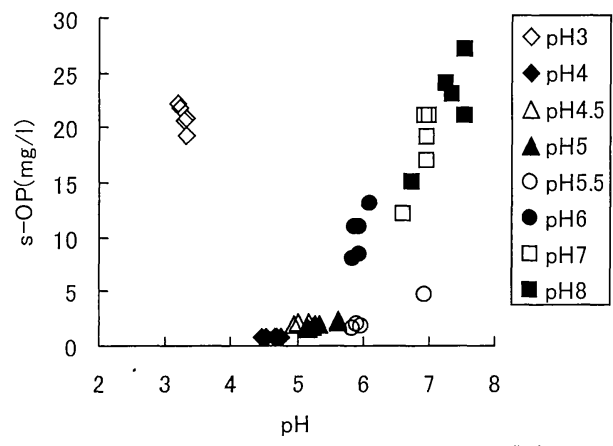

図-4アルミン酸ナトリウムの p Hと残留リン濃度

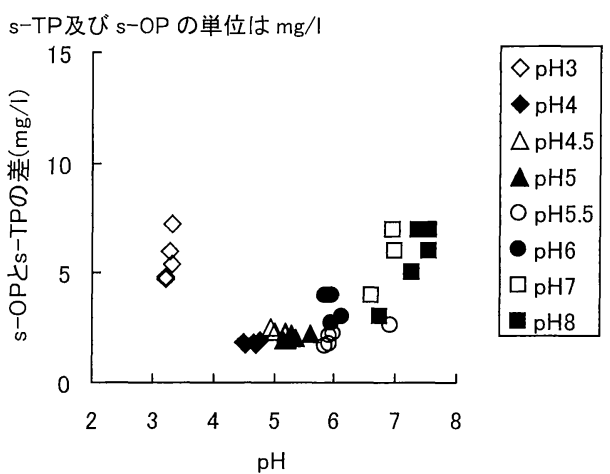

図-5 使用最適 $\mathrm{pH}$ と $\mathrm{s}$-TP と $\mathrm{s}-\mathrm{OP}$ の差 
泥は遠心分離を行っても SS 分と上澄みが鮮明に分離せ ず，濁った状態のままであった。

また，アルミン酸ナトリウムはアルカリ性溶液である

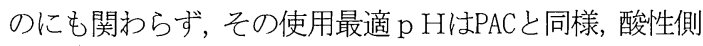
であった，このため，圧送污泥に使用する際には，硫酸 等で $\mathrm{p} \mathrm{H}$ 調整を行わなければその成果は発揮されない結 果となった.

c) ポリ硫酸第二鉄の使用最適 $\mathrm{p}$ Hとリン放出抑制効果 凝集剂としてポリ硫酸第二鉄（以下，ポリ鉄とする.)

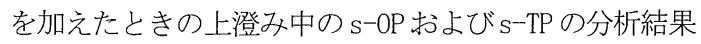
を表-5 に示す．比較のため表中に凝集剤を添加しなか

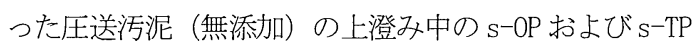
の分析結果もあわせて記載する. 図-6よりポリ鉄の使 用最適 $\mathrm{pH}$ H p H4 付近と考えられる. しかし, pH3 以下ではリン濃度およびその他の重金属濃度の上昇が 予想されるため, 使用可能な $\mathrm{p} \mathrm{H}$ 範囲はPAC およびアル ミン酸ナトリウムに比べて, はるかに狭い結果となった.

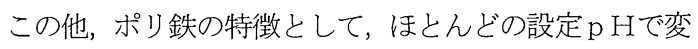
動後の $\mathrm{p} \mathrm{H}$ H関係なく時閒経過ともにリンの放出が見 られた。このとき凝集剂無添加の污泥から実験開始 30 分から 20 時間の間に放出されたリンは $5 \mathrm{mg} / 1$ であった. しかし， p H4より高い p Hに調整した污泥から放出さ
れたリンは 13〜23mg/1 であり, ポリ鉄は, 圧送污泥か ら新たに放出されたリンを補足できないだけでなく, 凝 集剂添加直後には補足していたリンを再び放出してし まうと推測された.このため, ポリ鉄は圧送污泥のリン を長時間, 污泥中にとどめる目的では使用できないと考 えられる.また, ポリ鉄では, 上澄み液中に鉄が残留し, この鉄イオンが時間経過とともに圧送污泥から発生す る硫化水素と反応するため, 污泥および上澄み液は時間 経過とともに黒変していく傾向が見られた.

\section{d) 各凝集剂の比較}

実験で使用した凝集剤の p H と残留リン濃度の比較を 図-7に示す. 結果から, 使用した凝集剤の中で最も使用 最適 $\mathrm{p} \mathrm{H}$ 範囲が広いのはPAC であり，その使用最適 $\mathrm{p} \mathrm{H}$ は，p H4.5から5.5であった。また，PACは他の凝集剤 と異なり, 多少, 使用最適 $\mathrm{pH}$ Hらはずれても，良好な リン除去性能を示した. アルミン酸ナトリウムでも使用 最適 $\mathrm{p} \mathrm{H}$ 範囲内では良好な結果が得られた. ポリ鉄では, 時間経過とともにリンが放出される結果となった。これ は，時間経過とともに，凝集剤添加直後には凝集剤の鉄 イオンと反応して, リン酸鉄となったリンが再び再溶解 したためと考えられる. これは, 圧送污泥は嫌気状態と なると, リンを放出するだけでなく硫化水素を発生する

表-5 ポリ鉄添加後の上澄み中のリン分析結果

\begin{tabular}{|c|c|c|c|c|c|c|c|c|c|c|c|c|}
\hline \multirow{3}{*}{$\frac{\text { 時間 }}{0.5}$} & \multicolumn{3}{|c|}{ 無添加 } & \multicolumn{3}{|c|}{$\mathrm{pH} 3$} & \multicolumn{3}{|c|}{$\mathrm{pH} 4$} & \multicolumn{3}{|c|}{$\mathrm{pH} 5$} \\
\hline & $\mathrm{pH}$ & $\mathrm{s}-\mathrm{O}$ & $\overline{s-T P}$ & $\overline{\mathrm{pH}}$ & $\mathrm{s}-\mathrm{Ol}$ & $\overline{s-T P}$ & $\mathrm{pH}$ & $\mathrm{s}-\mathrm{OF}$ & S-TP & $\mathrm{pH}$ & $\mathrm{s}-\mathrm{O}$ & s-TP \\
\hline & 5.6 & 25 & 29 & 3.6 & 1.3 & 2.5 & 4.4 & 0.73 & 1.4 & 5.1 & - & 2.6 \\
\hline 1 & 5.6 & 24 & 32 & 37 & 1.4 & 2.6 & 44 & 0.90 & 1.5 & 5.1 & 1.5 & 3.0 \\
\hline 2 & 5.5 & 27 & 34 & 3.7 & 1.4 & 2.8 & 4.5 & 1.2 & 2.0 & 5.2 & 2.4 & 3.9 \\
\hline 4 & 5.5 & 28 & 35 & 3.8 & 1.4 & 3.1 & 4.5 & 1.6 & 2.5 & 5.2 & 3.2 & 5.3 \\
\hline 20 & 5.0 & 30 & 37 & 3.9 & 2.6 & 4.8 & 4.7 & 11 & 14 & 5.0 & 16 & 20 \\
\hline
\end{tabular}

\begin{tabular}{|c|c|c|c|c|c|c|c|c|c|}
\hline \multirow[b]{2}{*}{ 時間 } & \multicolumn{3}{|c|}{$\mathrm{pH} 6$} & \multicolumn{3}{|c|}{$\mathrm{pH} 7$} & \multicolumn{3}{|c|}{$\mathrm{pH} 8$} \\
\hline & $\mathrm{pH}$ & $\mathrm{s}-\mathrm{OF}$ & $s-T P$ & $\mathrm{pH}$ & $\mathrm{s}-\mathrm{OF}$ & $s-T P$ & $\mathrm{pH}$ & $\mathrm{s}-\mathrm{OP}$ & $-T P$ \\
\hline 0.5 & 6.1 & 1.1 & 1.7 & 6.8 & 1.7 & 3.6 & 7.4 & 4.0 & 11 \\
\hline 1 & 6.1 & 1.6 & 2.6 & 6.7 & 2.7 & 5.1 & 7.2 & 4.1 & 11 \\
\hline 2 & 6.3 & 5.2 & 7.9 & 6.7 & 5.9 & 9.7 & 7.1 & 5.4 & 12 \\
\hline 4 & 6.2 & 6.5 & 8.6 & 6.6 & 6.8 & 11 & 7.0 & 6.4 & 13 \\
\hline 20 & 5.7 & 24 & 25 & 6.2 & 23 & 27 & 6.5 & 21 & 25 \\
\hline
\end{tabular}

$\mathrm{s}-\mathrm{TP}$ および $\mathrm{s}-\mathrm{OP}$ の単位は $\mathrm{mg} / \mathrm{l}$

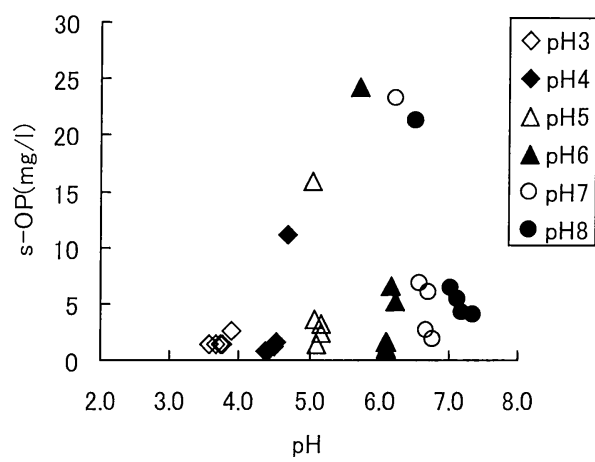

図-6 ポリ鉄の p Hと残留リン濃度

表-6 焼却灰中の重金属化合物の溶解度積 27)

\begin{tabular}{|c|c|c|c|}
\hline 金属塩 & $\mathrm{Ksp}\left(25^{\circ} \mathrm{C}\right)$ & 金属塩 & $\mathrm{Ksp}\left(25^{\circ} \mathrm{C}\right)$ \\
\hline $\mathrm{Fe}(\mathrm{OH})_{2}$ & $8 \times 10^{-16}$ & $\mathrm{FeS}$ & $6 \times 10^{-18}$ \\
$\mathrm{Fe}(\mathrm{OH})_{3}$ & $7.1 \times 10^{-40}$ & $\mathrm{FePO}_{4}$ & $1.3 \times 10^{-22}$ \\
\hline
\end{tabular}

$\Delta$ : PAC, ○ : アルミン酸, $\triangle:$ ポリ鉄

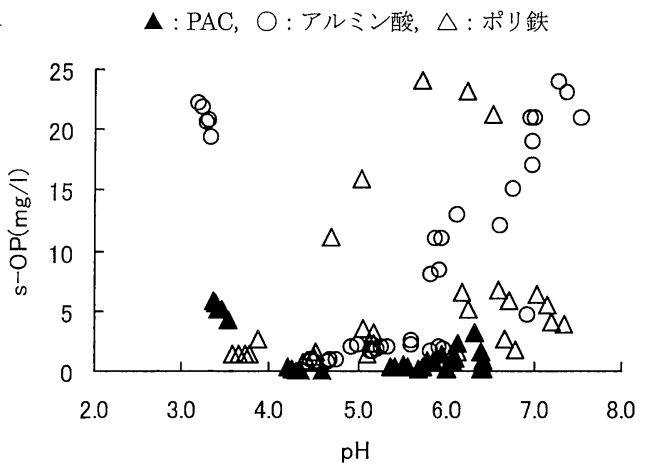

図-7 各凝集剤の使用 $\mathrm{pH}$ に対する残留リン濃度 
ため，式（7）もしくは式（8）に従って，鉄イオンが還 元され，硫化鉄になると考えられる ${ }^{26)}$. さらに表-6に示 す ${ }^{27)}$ ように, 水酸化鉄とリン酸鉄では溶解度積に若干の 差があり,生成したばかりのリン酸鉄は式(9)の反応によ って, 水酸化鉄を経て硫化鉄に変換され，このことで, 一度リン酸鉄として除去されたリンが再溶解する結果と なったと考えられる.

$$
\begin{aligned}
& 2 \mathrm{Fe}(\mathrm{OH})_{3}+3 \mathrm{H}_{2} \mathrm{~S} \Leftrightarrow \mathrm{Fe}_{2} \mathrm{~S}_{3}+6 \mathrm{H}_{2} \mathrm{O} \\
& \left.\begin{array}{l}
2 \mathrm{Fe}(\mathrm{OH})_{3}+\mathrm{H}_{2} \mathrm{~S} \Leftrightarrow \mathrm{Fe}(\mathrm{OH})_{2}+\mathrm{S}+\mathrm{H}_{2} \mathrm{O}+\mathrm{H}^{+} \\
\mathrm{Fe}(\mathrm{OH})_{2}+\mathrm{H}_{2} \mathrm{~S} \Leftrightarrow \mathrm{FeS}+2 \mathrm{H}_{2} \mathrm{O}
\end{array}\right\} \\
& \mathrm{FePO}{ }_{1}+3 \mathrm{H}_{2} \mathrm{O} \Leftrightarrow \mathrm{Fe}(\mathrm{OH})_{3}+\mathrm{H}_{3} \mathrm{PO}_{4} \\
& 2 \mathrm{Fe}(\mathrm{OH})_{3}+\mathrm{H}_{2} \mathrm{~S} \Leftrightarrow \mathrm{Fe}(\mathrm{OH})_{2}+\mathrm{S}+\mathrm{H}_{2} \mathrm{O}+\mathrm{H}^{+} \\
& \mathrm{Fe}(\mathrm{OH})_{2}+\mathrm{H}_{2} \mathrm{~S} \Leftrightarrow \mathrm{FeS}+2 \mathrm{H}_{2} \mathrm{O}
\end{aligned}
$$

\section{(2) 凝集剂添加した圧送污泥から得られた焼却灰の溶出 特性}

送泥直前の圧送污泥に各凝集剤を添加し，20時間静置 した後, 遠心分離によって上澄み液とSS分とに分離を行 った。この時の上澄み液に分析結果を表-7および表-8に 示寸.

凝集剤添加後, p H4に調整することで, 各試料とも最 終 $\mathrm{p} \mathrm{H}$ ガ $\mathrm{p} \mathrm{H}$ 5付近となり，各凝集剤の使用最適 $\mathrm{p} \mathrm{H内に}$ 収まり，上澄み中のリン濃度はいずれも低い結果となっ た. $\mathrm{p} \mathrm{H}$ 調整を行わない場合，アルカリ性凝集剤である

表-7 得られた上澄みの分析結果 ( $\mathrm{pH} 4)$

\begin{tabular}{cccccccc}
\hline & & \multicolumn{3}{c}{ リン } & & \multicolumn{3}{c}{ 重金属 } \\
\cline { 3 - 4 } \cline { 6 - 8 } $\mathrm{pH} 4$ & 最終pH & $\mathrm{s}-\mathrm{TP}$ & $\mathrm{s}-\mathrm{OP}$ & & $\mathrm{Zn}$ & $\mathrm{Fe}$ & $\mathrm{Al}$ \\
\hline Blank & 4.7 & 44 & 42 & & $\mathrm{ND}$ & 3.6 & $\mathrm{ND}$ \\
$\mathrm{PAC}$ & 5.0 & 0.39 & 0.19 & & $\mathrm{ND}$ & 3.4 & $\mathrm{ND}$ \\
アルミン酸 & 4.9 & 2.9 & 1.3 & $\mathrm{ND}$ & 3.6 & $\mathrm{ND}$ \\
ポリ鉄 & 4.9 & 0.55 & 0.31 & $\mathrm{ND}$ & 77 & $\mathrm{ND}$ \\
\hline
\end{tabular}

$\mathrm{pH}$ 以外の溶出濃度単位は $\mathrm{mg} / \mathrm{l}$
アルミン酸ナトリウムのみが使用最適 $\mathrm{p} \mathrm{Hを大きくはず}$ れ, 上澄み中のリン濃度も高い結果となった. また本来, 鉄イオンはp H未調整污泥の最終 p Hである p H6.4で は，水酸化鉄となって沈殿すると考えられるが，ポリ鉄 を使用した試料では上澄み中に高濃度の鉄が残留してお り，p H4および p H未調整でも; 添加した鉄の約 $50 \%$ が 上澄み中に残留した。 これは式(7)〜 (9)に示寸過程で二 価の鉄イオンが生成したためと考えられるが，二れ以外 にも污泥中の有機酸 (フミン酸類) とキレートを生成し, 上澄み中に残留したものと考えられる ${ }^{16)}$.

各凝集剤から得られた焼却灰のリンおよび重金属の含 有試験結果を， p H4および p H未調整に対して，表-9 および表-10のそれぞれ示す。この値をもとに得られた焼 却灰量から回収された各物質の総量の計算結果を $\mathrm{p} \mathrm{H} 4$ については表-11に, p H未調整は表-12に示す.

各分析結果に記載されているBlankは, 圧送污泥に凝集 凨を添加せず, $\mathrm{pH}$ Hもしくは p H未調整とし, その他の 試料と同様の操作を行ったもので, 凝集剤および $\mathrm{p} \mathrm{H}$ H調 整による影響を知ることができる，結果から p H調整の みを行っただけでは, ほとんどの物質について回収総量 は変化しなかった。 しかし, 凝集剤を添加し, 各凝集剤

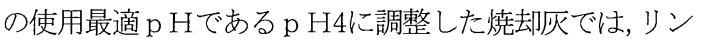
の回収総量はBlankにくらべてアルミニウム系凝集剂で 142\%，鉄系凝集剤で133\%に増大した。これは凝集剤によ って，本来，上澄み液に流出するリンが焼却灰中に保留 されたためである，また，凝集剤を使用することで，同 量の圧送污泥から発生する焼却灰は, Blankに比べて約

表-8 得られた上澄みの分析結果 ( $\mathrm{pH}$ 末調整)

\begin{tabular}{ccccccccc}
\hline & & \multicolumn{3}{c}{ リン } & & \multicolumn{3}{c}{ 重金属 } \\
\cline { 3 - 4 } \cline { 6 - 8 } $\mathrm{pH}$ 未調整 最終pH & $\mathrm{s}-\mathrm{TP}$ & $\mathrm{s}-\mathrm{OP}$ & & $\mathrm{Zn}$ & $\mathrm{Fe}$ & $\mathrm{Al}$ \\
\hline Blank & 6.5 & 45 & 44 & & $\mathrm{ND}$ & 1.7 & $\mathrm{ND}$ \\
$\mathrm{PAC}$ & 5.9 & 2.6 & 2.2 & & $\mathrm{ND}$ & 2.0 & $\mathrm{ND}$ \\
アルミン酸 & 7.8 & 19 & 16 & & $\mathrm{ND}$ & 0.8 & $\mathrm{ND}$ \\
ポリ鉄 & 6.4 & 7.4 & 7.2 & $\mathrm{ND}$ & 75 & $\mathrm{ND}$ \\
\hline & \multicolumn{3}{c}{$\mathrm{pH}$ 以外の溶出濃度単位は $\mathrm{mg} / 1$}
\end{tabular}

表-9 各凝集剤から得られた焼却灰の含有試験結果（pH4）

\begin{tabular}{ccccccccccccccc}
\hline $\mathrm{pH} 4$ & $\mathrm{Zn}$ & $\mathrm{Cd}$ & $\mathrm{Ni}$ & $\mathrm{Fe}$ & $\mathrm{Mn}$ & $\mathrm{Pb}$ & $\mathrm{Cu}$ & $\mathrm{Cr}$ & $\mathrm{As}$ & $\mathrm{Se}$ & $\mathrm{Ca}$ & $\mathrm{Mg}$ & $\mathrm{Al}$ & $\mathrm{P}$ \\
\hline Blank & 6100 & $<30$ & 91 & 18000 & 380 & 120 & 1700 & 90 & $<2.5$ & $<2.5$ & 38000 & 7200 & 80000 & 120000 \\
$\mathrm{PAC}$ & 5400 & $<30$ & 69 & 13000 & 190 & 85 & 1400 & 75 & $<2.5$ & $<2.5$ & 16000 & 6800 & 160000 & 140000 \\
アルミン酸 & 5000 & $<30$ & 73 & 13000 & 170 & 92 & 1500 & 73 & $<2.5$ & $<2.5$ & 14000 & 6100 & 140000 & 140000 \\
ポリ鉄 & 6000 & $<30$ & 84 & 110000 & 1400 & 88 & 1600 & 83 & $<2.5$ & $<2.5$ & 16000 & 5700 & 71000 & 140000 \\
\hline
\end{tabular}

表-10 各凝集剤からら得られた焼却灰の含有試験結果（pH 未調整）

\begin{tabular}{ccccccccccccccc}
\hline $\mathrm{pH}$ 未調整 & $\mathrm{Zn}$ & $\mathrm{Cd}$ & $\mathrm{Ni}$ & $\mathrm{Fe}$ & $\mathrm{Mn}$ & $\mathrm{Pb}$ & $\mathrm{Cu}$ & $\mathrm{Cr}$ & $\mathrm{As}$ & $\mathrm{Se}$ & $\mathrm{Ca}$ & $\mathrm{Mg}$ & $\mathrm{Al}$ & $\mathrm{P}$ \\
\hline Blank & 3100 & $<30$ & 110 & 22000 & 440 & 120 & 1700 & 90 & $<2.5$ & $<2.5$ & 34000 & 7500 & 71000 & 120000 \\
PAC & 2800 & $<30$ & 82 & 17000 & 350 & 95 & 1400 & 146 & $<2.5$ & $<2.5$ & 23000 & 5900 & 130000 & 130000 \\
アルミン酸 & 2500 & $<30$ & 73 & 17000 & 430 & 79 & 1400 & 79 & $<2.5$ & $<2.5$ & 34000 & 6300 & 110000 & 110000 \\
ポリ鉄 & 2800 & $<30$ & 110 & 120000 & 1900 & 93 & 1500 & 97 & $<2.5$ & $<2.5$ & 22000 & 6800 & 58000 & 130000 \\
\hline
\end{tabular}

単位は全て $\mathrm{mg} / \mathrm{kg}$ 
表-11 回収された各物質の総量 ( p H4)

\begin{tabular}{cccccccccccccccc}
\hline $\mathrm{pH} 4$ & 回収灰量 & $\mathrm{Zn}$ & $\mathrm{Cd}$ & $\mathrm{Ni}$ & $\mathrm{Fe}$ & $\mathrm{Mn}$ & $\mathrm{Pb}$ & $\mathrm{Cu}$ & $\mathrm{Cr}$ & $\mathrm{As}$ & $\mathrm{Se}$ & $\mathrm{Ca}$ & $\mathrm{Mg}$ & $\mathrm{Al}$ & $\mathrm{P}$ \\
\hline Blank & $1.02 \mathrm{~g}$ & 6.2 & - & 0.09 & 19 & 0.39 & 0.12 & 1.7 & 0.09 & - & - & 39 & 7.3 & 81 & 120 \\
PAC & $1.21 \mathrm{~g}$ & 6.6 & - & 0.08 & 16 & 0.23 & 0.10 & 1.7 & 0.09 & - & - & 19 & 8.2 & 190 & 170 \\
アルミン酸 & $1.19 \mathrm{~g}$ & 5.9 & - & 0.09 & 15 & 0.20 & 0.11 & 1.8 & 0.09 & - & - & 16 & 7.2 & 170 & 170 \\
ポリ鉄 & $1.16 \mathrm{~g}$ & 6.9 & - & 0.10 & 120 & 1.7 & 0.10 & 1.8 & 0.10 & - & - & 19 & 6.6 & 83 & 160 \\
\hline
\end{tabular}

表-12 回収された各物質の総量（p H未調整）

\begin{tabular}{cccccccccccccccc}
\hline $\mathrm{pH}$ 未調整 & 回収灰量 & $\mathrm{Zn}$ & $\mathrm{Cd}$ & $\mathrm{Ni}$ & $\mathrm{Fe}$ & $\mathrm{Mn}$ & $\mathrm{Pb}$ & $\mathrm{Cu}$ & $\mathrm{Cr}$ & $\mathrm{As}$ & $\mathrm{Se}$ & $\mathrm{Ca}$ & $\mathrm{Mg}$ & $\mathrm{Al}$ & $\mathrm{P}$ \\
\hline Blank & $1.01 \mathrm{~g}$ & 3.1 & - & 0.11 & 22 & 0.44 & 0.12 & 1.7 & 0.09 & - & - & 34 & 7.5 & 71 & 120 \\
$\mathrm{PAC}$ & $1.28 \mathrm{~g}$ & 3.6 & - & 0.11 & 21 & 0.45 & 0.12 & 1.8 & 0.19 & - & - & 29 & 7.6 & 170 & 170 \\
アルミン酸 & $1.29 \mathrm{~g}$ & 3.2 & - & 0.09 & 22 & 0.55 & 0.10 & 1.8 & 0.10 & - & - & 43 & 8.1 & 140 & 140 \\
ポリ鉄 & $1.19 \mathrm{~g}$ & 3.3 & - & 0.13 & 140 & 2.2 & 0.11 & 1.8 & 0.12 & - & - & 26 & 8.1 & 69 & 160 \\
\hline
\end{tabular}

衰-13 焼却灰の含有率と溶出濃度から計算された溶出割合 $(\mathrm{p} \mathrm{H}$ H)

\begin{tabular}{|c|c|c|c|c|c|c|c|c|c|c|c|}
\hline \multirow{3}{*}{$\mathrm{pH} 4$} & \multirow{3}{*}{$\begin{array}{c}\text { 使用した } \\
\text { 焼却灰量 } \\
\text { (g) }\end{array}$} & \multicolumn{5}{|c|}{ リン } & \multicolumn{5}{|c|}{ アルミニウム } \\
\hline & & \multicolumn{2}{|c|}{ 焼却灰 } & \multicolumn{2}{|c|}{ 上澄み } & \multirow[b]{2}{*}{ 溶出割合 } & \multicolumn{2}{|c|}{ 焼却灰 } & \multicolumn{2}{|c|}{ 上澄み } & \multirow[b]{2}{*}{ 溶出割合 } \\
\hline & & 含有 & 総量 & 溶出濃度 & 総量 & & 含有 & 総量 & 溶出濃度 & 総量 & \\
\hline Blank & 0.4992 & 120000 & 62 & 610 & 30 & $49 \%$ & 80000 & 40 & 430 & 21 & $53 \%$ \\
\hline PAC & 0.5001 & 140000 & 70 & 1200 & 58 & $84 \%$ & 160000 & 78 & 830 & 42 & $54 \%$ \\
\hline アルミン酸 & 0.5007 & 140000 & 70 & 1100 & 56 & $81 \%$ & 140000 & 70 & 790 & 39 & $57 \%$ \\
\hline ポリ鉄 & 0.5003 & 140000 & 69 & 940 & 47 & $68 \%$ & 71000 & 36 & 570 & 28 & $80 \%$ \\
\hline
\end{tabular}

単位 : 含有は $\mathrm{mg} / \mathrm{kg}$, 溶出濃度は $\mathrm{mg} / \mathrm{l}$, 総量は $\mathrm{mg}$

表-14 焼却灰の含有率と溶出濃度から計算された溶出割合（p H未調整）

\begin{tabular}{|c|c|c|c|c|c|c|c|c|c|c|c|}
\hline \multirow{3}{*}{ pH未調整 } & \multirow{3}{*}{$\begin{array}{c}\text { 使用した } \\
\text { 焼却灰量 } \\
\text { (g) }\end{array}$} & \multicolumn{5}{|c|}{ リン } & \multicolumn{5}{|c|}{ アルミニウム } \\
\hline & & \multicolumn{2}{|c|}{ 焼却灰 } & \multicolumn{2}{|c|}{ 上澄み } & \multirow[b]{2}{*}{ 溶出割合 } & \multicolumn{2}{|c|}{ 焼却灰 } & \multicolumn{2}{|c|}{ 上澄み } & \multirow[b]{2}{*}{ 溶出割合 } \\
\hline & & 含有 & 総量 & 溶出濃度 & 総量 & & 含有 & $\begin{array}{l}\text { 総量 } \\
\end{array}$ & 溶出濃度 & 総量 & \\
\hline Blank & 0.5011 & 120000 & 62 & 610 & 31 & $49 \%$ & 71000 & 35 & 400 & 20 & $57 \%$ \\
\hline PAC & 0.5001 & 130000 & 65 & 910 & 46 & $70 \%$ & 130000 & 67 & 740 & 37 & $55 \%$ \\
\hline アルミン酸 & 0.5009 & 110000 & 56 & 500 & 25 & $45 \%$ & 110000 & 55 & 450 & 22 & $41 \%$ \\
\hline ポリ鉄 & 0.5018 & 130000 & 66 & 720 & 36 & $55 \%$ & 58000 & 29 & 450 & 23 & $78 \%$ \\
\hline
\end{tabular}

単位 : 含有は $\mathrm{mg} / \mathrm{kg}$, 溶出濃度は $\mathrm{mg} / \mathrm{l}$, 総量は $\mathrm{mg}$

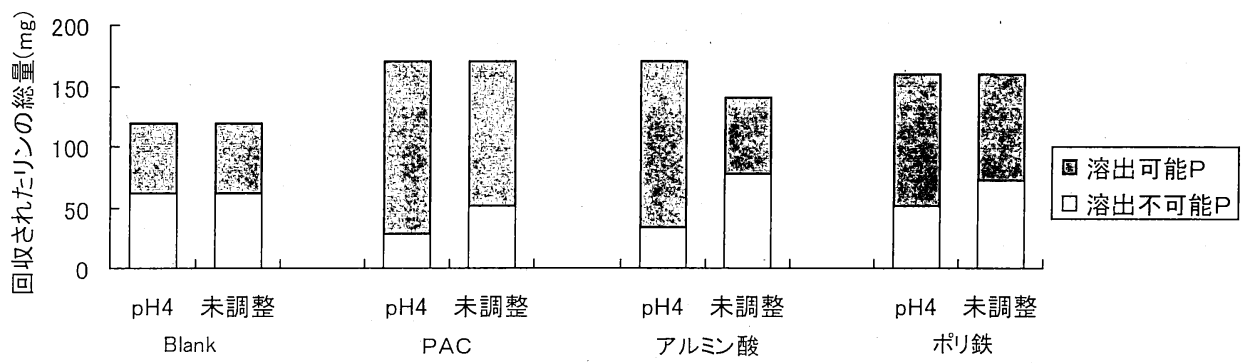

図-8 焼却灰として回収されたリンの総量と溶出可能なリンの割合

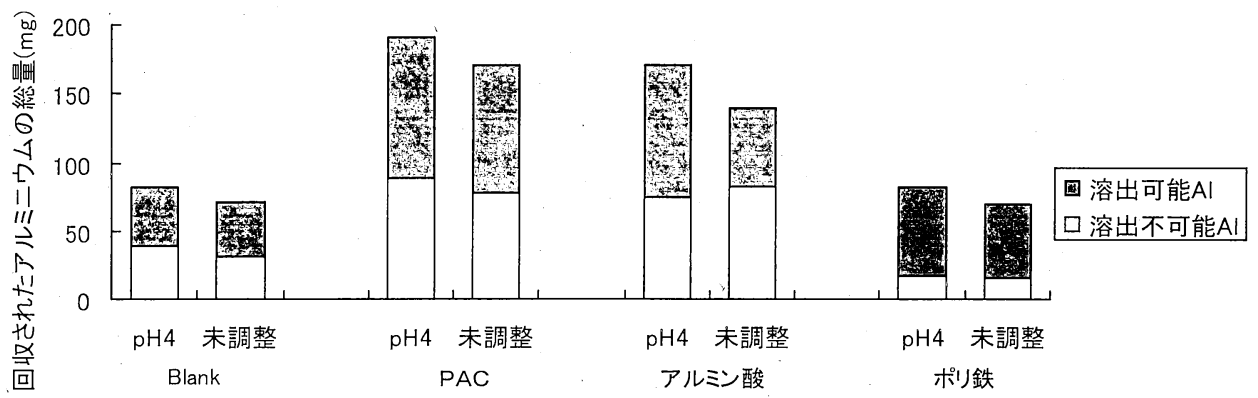

図-9 焼却灰として回収されたアルミニウムの総量と溶出可能なアルミニウムの割合 
1.2倍量と増大した. このため, 焼却灭中のリン含有量は PAC使用時で1. 16倍程度の増大にとどまった. 各凝集剤を 添加し $\mathrm{p} \mathrm{H}$ 調整を行わない場合, アルカリ性凝集剤であ

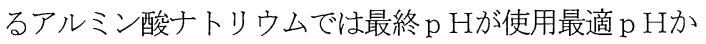
ら大きく外れた.このため回収されたリンの回収総量は, Blank と比較して116\%となった. しかし, 添加された凝集 剤によって焼却灰の回収量が増大したため，焼却灰中の リン濃度はBlankに対して92\%と低下した。これはアルミ ン酸ナトリウム中のアルミニウムがリン酸アルミニウム としてではなく, 水酸化アルミニウムとして沈殿した割 合が，他の凝集剤より大きいためと推測される.

次に, 得られた焼却灰のアルカリ溶出と, これらの結 果から計算されたリンとアルミニウムの溶出割合を, 表 -13および14に示す.さらにその中から焼却灰中のリンの 総量とそのうちの溶出可能なリンと溶出不可能なリンの 割合を図-8に，アルミニウムの割合を図-9に示す。

通常，焼却灰のアルカリ溶出は亜鉛の溶出を押さえる ため, 溶出温度 $40^{\circ} \mathrm{C}$, 焼却灰に対して $0.2 \mathrm{~g} \mathrm{NaOH} \cdot \mathrm{g}$ dry $\mathrm{ash}^{-1}$ のアルカリ濃度で行われる.このため, リン酸アル ミニウムより溶解度の低い水酸化アルミニウム等のアル ミニウム化合物はほとんど溶出しなかった ${ }^{122}$. 本実験で アルカリ溶出時，かなり過剩のアルカリを使用すること で, 本来のアルカリ溶出では溶出することのないアルミ ニウムが溶出してしまう。このため, 使用したアルカリ 濃度は10\%程度とした。結果から，Blankから得られた焼 却灰の溶出割合は，実際に污泥焼却施設から得られる焼 却灰とほぼ同様の溶出割合を示し，過剩アルカリを使用 したことによるアルミニウムの過剩溶出は認められなか った。ささらに，Blankでは p H4と p H未調整の間では回 収されたリンの総量および溶出割合に違いは見られず, $\mathrm{p} \mathrm{H}$ 調整で使用した硫酸はリン回収に影響を与えないこ とが確認された.

凝集剂を添加し, 生成した焼却灰の溶出試験結果より PAC ではp H 4 およびp H未調整では回収されたリンの 総量にほとんど差が見られなかったＰAC は他の凝集剤 と違い, 広い $\mathrm{p} \mathrm{H}$ 範囲でリンの除去効果があるため, $\mathrm{pH} 4$ と p H未調整の間で，上澄み中のリン濃度に差が 出なかったことが原因として挙げられる. しかし, 溶出 割合には差が見られ，pH4 付近に調整することで，よ り多くのリンが溶出可能となった.

アルミン酸ナトリウムでは，pH4 に調整することで PAC とほぼ同様の回収量と溶出割合を示した。 しかし， $\mathrm{p} \mathrm{H}$ 末調整の場合, リンの溶出割合は最も低かった.

ポリ鉄でも p H4 および p H未調整ともに，焼却灰中 に回収されたリンの溶出割合は，大幅に改善される結果 となった。 またアルミニウムも回収総量はBlank とほぼ 同量だったにもかかわらず，溶出割合も大幅に改善され
た.

このように凝集剤を添加し，生成した焼却灰は， p H 調整した場合としなかった場合では，その溶出可能なリ ンとアルミニウムの割合が変化した。これは，アルカリ 溶出しやすいリン酸アルミニウムとして回収されたリン の割合が異なるためである. 特にアルミン酸ナトリウム ではその影響が大きく, 表-13および図-8 に示されるよ うに, リンの溶出割合は p H未調整では 45\%であったも のが, $\mathrm{pH}$ 調整を行うことで $81 \%$ まで改善された. $\mathrm{pH}$ 調整を行うことで焼却灰中に回収できたリンの総量はす でに 1.25 倍であるため, そこからアルカリ溶出によって 回収できるリンの総量は, pHも調整に比べて 2.24 倍 と増大した. また, $\mathrm{pH}$ 調整の影響を最も受けない PAC の場合でもその溶出割合は70\%から 84\%に増大した。

この理由として表-9，10 に示すように $\mathrm{pH}$ 調整を行っ た污泥と, pH未調整の污泥から得られた焼却灰ではカ ルシウム濃度が異なる.これは, 硫酸のみの添加 ( p H4, Blank）ではカルシウム含有量が変化しないことから, 凝 集剤と硫酸を添加したことにより，アルカリ溶出しにく いリン酸カルシウムの生成が抑制され，リンの溶出割合 が増大したと考えられる. また，ポリ鉄添加灰でもアル ミニウムの溶出割合が改善された。これらは，図-10211 に示すように p H4〜6 の間では, リン酸アルミニウムが 最も溶解度が低く，生成しやすいため，(1)圧送污泥が嫌 気状態になること，(2)凝集剤によりアルミニウムもしく は鉄イオンが大量に供給されたこと, (3)硫酸によって p H調整を行ったことで, リンが圧送污泥中に存在して いるアルミニウムと結びつき, リン酸アルミニウム含有 量が増大したと考えられる.このように，リンがリン酸 鉄やリン酸カルシウムでなく, リン酸アルミニウムとし て回収されたため, アルミニウム系凝集剂ではリンの溶 出割合が，鉄系凝集剤ではリンとアルミニウム両方の溶 出割合が増大したと考えられる.

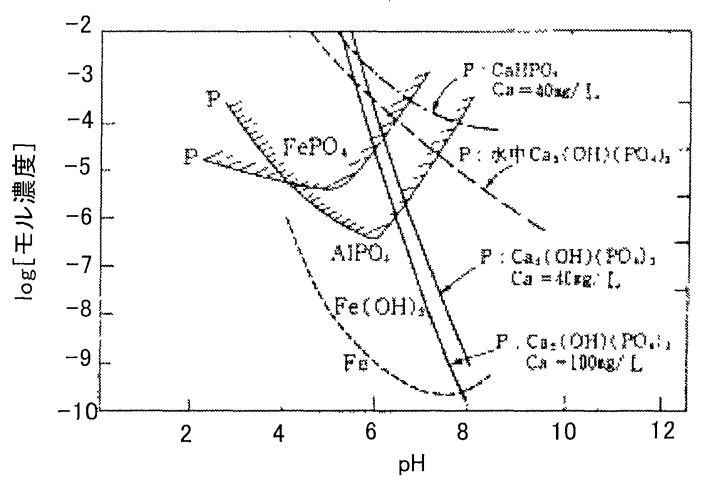

図-10 主なリン化合物の $\mathrm{p} \mathrm{H}$ と溶解度の関係 


\section{4 まとめ}

これまでの実験から以下のことが確認された.

（1）圧送污泥にアルミニウム凝集剤を使用寸ることで, 污泥からのリンの放出を抑えることができた.

（2）圧送污泥に凝集剤を使用する際，凝集剤は污泥中の 塩類の影響を強く受けるため, 使用最適 $\mathrm{p} \mathrm{H}$ H, 低 $\mathrm{p} \mathrm{H}$ 側に移行する. この中でも PAC の使用最適 $\mathrm{p} \mathrm{H}$ は最も $\mathrm{p} \mathrm{H}$ 範囲が広かった。

（3）PACを使用した後，p H4 に調整し，得られた焼却灰 には，より多くのリン酸アルミニウムが生成し，ア ルカリ溶出可能なリンの割合が 49\%から 84\%に増大 した.

（4）アルミン酸ナトリウムの使用最適 $\mathrm{p} \mathrm{H}$ H, $\mathrm{p} \mathrm{H} 4$ 〜 5 であった，しかし，この $\mathrm{pH}$ 範囲をはずれるとリン 除去性能は急激に低下し，得られた焼却灰中のリン の溶出割合も改善されなかった.

（5）ポリ鉄の使用最適 $\mathrm{p} \mathrm{H}$ は， p H4 4 4.5 と最も狭く, 上澄み中には多くの鉄イオンが残留した。この鉄イ オンが時間経過とともに污泥から発生する硫化水素 と反応し，時間経過とともにリンが放出された.

以上, 実験の結果をまとめると圧送污泥中のリンの放 出を抑えるためには，時閒経過とともにリンを放出する ポリ鉄ではなく，アルミニウム系凝集剂を使用すること が望ましく, 特に, 使用最適 $\mathrm{p} \mathrm{H}$ 領域の広い PAC が有効 であると考えられる，また，PAC は酸性凝集剤であり， 圧送污泥に凝集剤を添加する際, 使用最適 $\mathrm{p} \mathrm{H}$ H酸性側 に移行するため, p H 調整なしで使用最適 $\mathrm{pH}$ Hにする ことができた，さらに，硫酸を加えて p Hを若干調整す ることで更に焼却灰中のリン酸アルミニウムの割合が増 加し，より多くのリンが，焼却灰から回収できる結果と なった.

都市部の下水污泥は集約処理が進められており，その 圧送中に多くのリンが污泥から放出され，それが返流水 中のリン負荷を増大させる原因の一つであった. しかし， 本研究により, 圧送污泥もしくは水処理中に使用された アルミニウム系凝集剤が，圧送中のリンの放出を防ぐ働 きがあることが明らかになった。

著者らはこれまで, アルカリ溶出による焼却灰からの リンの資源回収について実験を行ってきた。しかし・ア ルカリ溶出では, 焼却灰中のリンの約 $50 \%$ しか溶出, 回収 することができなかった。しかし，圧送污泥に疑集剤を 添加後, p H調整を行うことで焼却灰中の溶出可能なり ンの割合を大幅に増大させ，多くのリンを溶出すること に成功した，このため，図一1に示した資源循環を効率よ く行うことができる. また，アルカリ溶出で得られたア ルミン酸ナトリウムはそのまま凝集剤としてではなく,
バイヤー法28), 299 等により水酸化アルミニウムと水酸化ナ トリウムに分離回収し, 水酸化アルミニウムからPACを生 成後, 使用する方が効率のよい資源循環が成立すると考 えられる。

また, 今後, 高度処理の導入により返流水中のリンは 高濃度化が予想され,このリンによる過負荷を防ぐ上で, 本研究の成果は有効であると考える.

謝辞 : 本研究にあたり, 多くの方々から御協力と貴重な 御助言を賜りました。ここに記して謝意を表します.

\section{参考文献}

1）高橋一彰：下水污泥処理および有効利用の変換と現状, 再 生と利用, 26, No. 98, pp. 98-102, 2003.

2）村上孝雄: 生物学的脱リン法における污泥処理返流水リン 負荷の影響とその削減方法に関する一考察, 下水道協会誌, Vol.26, No.296, pp. 19-30, 1989.

3）佐藤三男, 五井正季, 窪田雅一, 局俊明, 宮田純, 角田明 彦，宮永浩三: 下水污泥集約処理施設における物質収支と 返流水リン負荷に関する調查, 第 36 回下水道研究発表会 講演集, pp. 803-805, 1999.

4）佐々間真理子, 石井実: 東京都流域下水道 6 処理場におけ る $\mathrm{A}_{2} \mathrm{O}$ 法施設の処理実績と課題について, 第 40 回下水道 研究発表会, pp. 724-726, 2003.

5）岩部秀樹，小出典宏，小松敏宏：リン挙動モデルを用いた 污泥集約処理施設へのリン負荷とその形態予測, 環境衛生 工学研究, Vol. 13, No. 3, pp. 26-31, 1999.

6）三品文雄，新保高之：下水污泥リン資源化の必要性，再生 と利用, Vol. 26, No. 98, pp. 13-18, 2003.

7）中原啓介, 南條行雄 : 下水污泥焼却灰の還元溶融による黄 リン製造，再生と利用，Vol. 26，No. 98，pp. 67-73, 2003.

8）吉田佳子, 洙田泰臣, 高橋泰弘 : 焼却灰からのリンのリン 酸ナトリウムとしての回収実験, 第3 8 回下水道研究発表 会, pp. 836-838, 2001.

9）吉田佳子, 高橋泰弘, 秦野正人：下水污泥焼却灰からのリ ンのリン酸ナトリウムとしての回収実験, 第 12 回廃棄物 学会研究発表会, pp. 280-282, 2001.

10）高橋泰弘, 吉田佳子, 洙田泰臣, 曽根康夫 : 污泥焼却灰に 含まれる有価物の効率的な回収に関する研究下水道協会 誌, Vol. 38, No. 468, pp. 181-192, 2001

11）吉田佳子, 高橋泰弘, 秦野正人, 宇城碩弥 : 污泥焼却灰の リンとアルミニウムの実用的な回収に関する研究，下水道 協会誌, Vol. 39, No. 482, pp. 107-120, 2002.

12）吉田佳子, 野池達也: 下水污泥焼却灰のアルカリ溶出に及 ぼす温度の影響, 土木工学会論文集, 投稿中

13) Abrahamson, H. B., Rezvani, A. B. and Brushmiller, J. G. : Photochemical and spectroscopic studies of complexes of iron(III) with citric acid and other carboxylic acids, Inorganica Chimica Acta, Vo1.226, pp. 117-127, 1994.

14）凝集沈殿，用廃水管理叢書編集委員会，1966.

15）渡辺昭二，武本剛，原直樹，木村文智，長坂實上，佐藤義 典: 実下水を用いた連続実験装置による凝集剂注入特性の 検討, 第 37 回下水道研究発表会講演集, pp. 521-523, 2000.

16）加尔肯馬拉夫, 穂純純, 吉田英樹, 吉田智志, 菅原崇: 硫 酸ばん土, PAC および篮化第二鉄による下水 2 次処理水の 凝集直接万過, 環境工学研究論文集, Vol. 34, pp. 391-398, 1997. 
17）岩部秀樹，堅田智洋，小松敏宏：無機凝集剤を併用した下 水高度処理システムの処理特性, 環境衛生工学研究, No. 10, Vol. 3, pp. 251-256, 1996.

18）森田隆嘉: 凝集剤添加・担体投入型無酸素一微好気一好気法, 下水道協会誌，Vol.40, No. 486, pp. 45-49，2003.

19）料治重徳, 河嶋淳平: 凝集剤併用循環式消化脱窒法 (酸化 法）の運転特性，下水道協会誌，Vol. 40, No. 487, pp. 127-134, 2003.

20）宗宮功，児林宏之: 活性污泥法によるリンの挙動と除去効 果, 下水道協会誌, Vol.20, No.224, pp. 9-16, 1983.

21）事業場排水指導指針一-2002 年版一,（社）日本下水道協会

22）高橋正宏, 諏訪守, 奥井淳: リンの超高度除去と回収シス テムの開発に関する研究 (I ) リンの超高度除去に関する 研究, 環境保全研究成果集（II)，平成 5 年度版.

23）薬品ハンドブックー第 3 版一，栗田工業， 1977.

24）大蔵武，京墓賢二，後藤克巳 : 水酸化アルミニウムの凝集 に対する共存物の影響, 工業用水, No. 52, pp. 1406-1412, 1963.
25）張元月，中村文雄 : Fe, Al 系凝集剤のフロック形成とその 特性に関寸る研究，工業用水，No. 521，2002.

26）丸田浩二，東俊行：下水処理施設から発生する硫化水素の 薬品（ポリ鉄）添加による抑制，下水道協会誌，Vol.34， No. 374，pp. 98-106， 1994

27）松永旭，関根孝夫 : 滴定法による消化污泥のリン酸態リン 濃度の測定, 用水と廃水, Vol. 36, No. 2, pp. 138-143, 1994.

28) Maier, A. A. and Lapin, A. A. : Infuence of chamosite on technological indices of processing of the vezhayu-vorykvinsk (sredne-timan) bauxites using the bayer technique, Russian Journal of Non-Ferrous Metals, Vol. 41, No. 1, pp. 13-19, 2000.

29）佐藤太一 : 水酸化アルミニウムとアルミナについて，鉱物 学雑誌, Vol. 19, No. 1, pp. 21-41, 1989.

(2003.11.17 受付)

\section{A STUDY ABOUT INCREASE OF QUANTITY OF PHOSPHORUS COLLECTION BY ALKALINE ELUTION OF INCINERATOR ASH OF SEWAGE SLUDGE}

\section{Yoshiko YOSHIDA and Tatsuya NOIKE}

A phosphate rock is one of the natural resources of which exhaustion have been recognized in the world. Incinerator ash of sewage sludge is a hopeful substitute resource of phosphate rock. In this study, the increase in phosphorus recovery efficiency in the alkaline elution of incinerator ash of sewage sludge was investigated by adding coagulants to the sludge transported with pressure. PAC, sodium aluminate and poly-iron sulfate were used as coagulants. As a result, coagulant restrained phosphorus discharged from sludge by $\mathrm{pH}$ adjustment and decreased phosphorus in supernatant. PAC has wide range of use optimum $\mathrm{pH}$ and phosphorus recovery efficiency by alkali solution increased from $49 \%$ to $84 \%$ at $\mathrm{pH} 4$. 